\title{
Vision-Related Quality of Life in Ocular Hypertension Patients: Effects of Treatment
}

\author{
Maria Kazaki', Ilias Georgalas¹, Alexandros Damanakis', Georgios Labiris², \\ Sergios Taliantzis ${ }^{1 *}$, Chryssanthi Koutsandrea1, Dimitris Papaconstantinou ${ }^{1}$ \\ ${ }^{1}$ Department of Glaucoma, University of Athens, Athens, Greece \\ ${ }^{2}$ Department of Ophthalmology, University of Alexandroupolis, Alexandroupolis, Greece \\ Email: sergiotali@hotmail.com
}

Received 25 January 2015; accepted 13 February 2015; published 15 February 2015

Copyright (C) 2015 by authors and Scientific Research Publishing Inc.

This work is licensed under the Creative Commons Attribution International License (CC BY).

http://creativecommons.org/licenses/by/4.0/

(c) (i) Open Access

\section{Abstract}

Purpose: To evaluate the quality of life related to vision (QoL) in patients with ocular hypertension under treatment. Methods: The study included two groups. The first one consisted of 60 ocular hypertension patients under topical hypotensive medications and the second one of 60 healthy persons. The Greek language version of the National Eye Institute Visual Function Questionnaire 25 (NEI VFQ-25) was completed by all patients. Results: The median scores of the total score and also for almost all the NEI VFQ-25 subscales were significantly decreased for the first group of ocular hypertension patients (OHT) under topical therapy. Females presented higher QoL than that of males. The patients who used one medication presented higher QoL than that of the patients who used more than one. The best corrected visual acuity (BCVA) and the intraocular pressure (IOP) were significantly correlated with QoL. The index of the visual fields, pattern standard deviation (PSD), was significantly related to the quality of life of OHT. The age, the cup to disk ratio and the central corneal thickness had also significant correlations with subscales of the QoL. Conclusions: The quality of life OHT patients under topical treatment is significantly decreased than healthy persons. Male sex and the number of medications affect QoL more. BCVA and IOP represent the clinical findings that best correlate with several subscales of QoL. PSD is a significant index that correlates well with the quality of life of OHT patients.

\section{Keywords}

Intraocular Pressure, Ocular Hypertension, Quality of Life, VFQ-25

\footnotetext{
${ }^{*}$ Corresponding author.
} 


\section{Introduction}

Ocular hypertension (OHT) describes the condition in which the intraocular pressure lies above the $21 \mathrm{mmHg}$, with normal appearance of the optic nerve head and with visual fields with no signs of glaucomatous damage [1].

Since elevated IOP is the major risk factor for the development of glaucomatous visual loss, finding a "raised" intraocular pressure (IOP) indicates the need for further investigation. The decision to treat a patient with ocular hypertension should be made when the risk factor(s) are considered to outweigh the disadvantages of treatment [2]-[4].

Glaucoma and associated visual changes may negatively affect quality of life because of progressive visual field deterioration and lifetime treatment [5]. Multicenter studies such as the Ocular Hypertension Treatment Study (OHTS) and Collaborative Initial Glaucoma Treatment Study (CIGTS) have included questionnaires to evaluate quality of life related to vision (QoL) [6]-[8]. Intraocular pressure, visual field results and patient adherence cannot be used to assess the subjective experience of the quality of vision [9]. Furthermore, medication for treatment of glaucoma is negatively correlated with adherence and quality of life related to vision in patients with glaucoma [10].

Ocular hypertension patients represent a group with still mild glaucomatous type alterations but that may need treatment. The quality of life these patients has not been still evaluated nor the impact that topical medications have on them. To our knowledge a study of Wolfram and others included an ocular hypertension group but focused mainly on glaucomatous patients [11]. Instead this study examines QoL of OHT patients and its characteristics.

We hypothesized that the pharmacological treatment influences negatively QoL of OHT patients. The purpose of this study is to assess the quality of life related to vision of OHT patients under topical medications and the effect that those have on QoL.

\section{Materials and Methods}

\subsection{Subjects}

The study followed the guidelines of the Declaration of Helsinki and was approved by the ethics committee of G. Gennimatas Athens General Hospital. Informed consent was obtained from all subjects. For the purpose of our study, two groups meeting the inclusion criteria were considered. The first group included the first sixty patients with ocular hypertension that visited our department. Instead the second group included the first healthy sixty people with no ocular history.

Inclusion criteria for the first group were ocular hypertension under topical treatment with IOP up to 18 mmHg; abnormal appearance of optic nerve head; best corrected visual acuity (BCVA) 0.7 or better on Snellen chart test with spherical refractive error from $-6.00 \mathrm{D}$ to $+3.00 \mathrm{D}$. Inclusion criteria for the second group were individual with no history of ocular diseases nor use of medication for the eyes, BCVA 0.7 or better on Snellen chart test with spherical refractive error from $-6.00 \mathrm{D}$ to $+3.00 \mathrm{D}$, IOP up to $20 \mathrm{mmHg}$, vertical cup to disk ratio up to 0.4 and difference between the two eyes up to 0.2 with normal appearance of the optic disk and physiological visual fields. Abnormal appearance findings of optic nerve head include vertical cup-to-disc diameter ratio of $>0.7$ or asymmetry of cup/disc ratio (C/D) of $>0.2$, cup extension nasal to the rim vessels, kinking of the retinal vessels, baring of the circumlinear vessel and presence of splinter hemorrhages [12].

Exclusion criteria were glaucomatous or other findings on visual fields examination based on the Anderson-Patella criteria; IOP > $18 \mathrm{mmHg}$; ocular comorbidities such as diseases of the cornea, anterior chamber, lens, vitreous cavity, and retina that may reduce visual acuity; history of intraocular surgery; history of chronic systemic diseases that may affect general health; treatment duration of less than six months.

\subsection{Evaluation}

A specific examination protocol was applied to all patients, including general and ophthalmic history and complete ophthalmic examination that included determination of best corrected visual acuity, slit lamp examination, intraocular pressure measurement, fundus biomicroscopy, central corneal thickness measurement, C/D appreciation and visual fields examination.

The best corrected visual acuity was determined from Snellen chart testing. Slit lamp examination was per- 
formed to evaluate the anterior and posterior chambers. Fundus examination was performed with a (+78) D lens after dilation of the pupil with $1 \%$ tropicamide and $2.5 \%$ phenylephrine drops.

Intraocular pressure was determined with a Goldman applanation tonometer. All patients of the first group already used topical hypotensive therapy and underwent IOP measurement three times a day for three consecutive days. Topical treatment included prostaglandine analogs, $\beta$-blockers, carbonic any drase inhibitors, sympathomimetic and/or combination of the above. Central corneal thickness was measured with an ophthalmic ultrasonography system (Ocuscan RxP, Alcon Alcon Laboratories Inc, USA, city, state). Heidelberg Retina Tomograph was used to assess C/D (Heidelberg Engineering GmbH, Heidelberg, Germany). Visual field examination was performed with a white on white perimetry using the Swedish Interactive Threshold Algorithm standard 30-2 strategy (Humphrey Field Analyzer, Humphrey-Zeiss Systems, Dublin CA). A minimum 2 tests were performed to minimize the learning effect; if any 2 tests failed to satisfy the reliability criteria defined by the perimeter (false positive, false negative, and loss of fixation), the test was repeated. The Anderson-Patella criteria was used with 3 non edge points depressed to an extent of what is present in $<5 \%$ of normal population with at least 1 point of these 3 depressed to an extent found in less than $1 \%$ of normal population, pattern standard deviation and corrected pattern standard deviation (PSD/CPSD) should be that found in $<5 \%$ population and glaucoma hemifield test (GHT) should be "OUTSIDE NORMAL LIMITS" [13].

\subsection{Questionnaire}

The 25-item National Eye Institute Visual Function Questionnaire (NEI-VFQ 25) included questions about visual function of patients with chronic ophthalmic diseases. It had been developed for evaluation of patients with agerelated cataracts, glaucoma, age-related macular degeneration, and diabetic retinopathy. The main purpose of the VFQ-25 was to assess the effect of ophthalmic diseases and related symptoms on the quality of life and social function of patients [14]. Several studies used this questionnaire to assess the quality of life of glaucoma patients [15]-[17]. The 25 questions had been grouped in 12 categories that were related to vision, and the total time requested to answer the entire questionnaire was 10 minutes [18]. The response to each question was converted in a 0 to 100 scale (lowest score, 0 ; highest score, 100). For each category, the mean score was calculated from the associated questions for the category. The total score for the entire questionnaire was calculated as the mean of the scores of the 12 subscales [19] [20]. The Greek language edition of NEI VFQ-25 was used [21].

\subsection{Data Analysis}

Data were analyzed using statistical software (SPSS for Windows 12.00, SPSS Inc., Chicago, IL). The Kolmogorov-Smirnov test was used to control the normality of the distribution. All the descriptive parameters were noted in the form of mean and standard deviation (SD) if the data were parametric or in the form of median with interquartile range if the data were nonparametric. Comparisons for normal distribution between the two groups were calculated using the Mann-Whitney $U$ test for non parametric data and the independent sample t-test for parametric data. Correlations between quality of life and other variables were evaluated with the Spearman rank correlation. The multivariate linear regression analysis and the stepwise method, was used to calculate the significance that the clinical findings have on QoL. Statistical significance was defined by $P \leq 0.05$.

\section{Results}

One hundred and twenty persons were included in the study, in two separated groups. The first one included 60 OHT patients under topical treatment, thirty four women and twenty six men. The second group included 60 healthy people, thirty six women and twenty four men. Table 1 presents the descriptive data and clinical characteristics of the two groups.

The main age of OHT group was higher than the healthy group $(61 \pm 6.23$ and $57.31 \pm 11.2$ years of age respectively), with significantly worst BCVA $(P=0.0001)$, higher CD $(0.6 ; P=0.0001)$ and CCT of $525 \mu \mathrm{m}$, lower than the second group $(P=0.001)$. The global indices of the visual fields between the two groups were also significant different, with the mean MD and PSD of the first group to be $-0.73 \mathrm{db} \pm 0.93(P=0.0001)$ and $1.87 \mathrm{db} \pm 0.52$ respectively $(P=0.0001)$. The median number of medication of the first group was 2 with interquartile range from 1 to 2 and with interquartile range from 1 to 2 the median number of instillations to be 3 with interquartile range from 1 to 3 . The median IOP of OHT under medication was $15 \mathrm{mmHg}$. The second group did not use treatment and had a median IOP of $13 \mathrm{mmHg}$. 
Table 1. Descriptive data and Clinical Characteristics of the two groups.

\begin{tabular}{cccc}
\hline Characteristic & First Group & Second Group & Probability Significance(S) \\
\hline No. patients & 60 & 60 & - \\
Sex (female/male) & $34 / 26$ & $36 / 24$ & \\
Age (years) & $61.18 \pm 6.23$ & $57.31 \pm 11.2$ & S (0.001) \\
Best corrected visual acuity & $10(9-10)$ & $10(10-10)$ & S (0.0001) \\
Intraocular pressure (mmHg) & $15(14-16)$ & $13(12-15)$ & S (0.0001) \\
Daily number of medications & $2(1-2)$ & 0 & NA \\
Daily number of instillations & $3(1-3)$ & 0 & NA \\
Cup to disc ratio & $0.6(0.5-0.7)$ & $0.2(0.1-0.3)$ & S (0.0001) \\
Central corneal thickness $(\mu \mathrm{m})$ & $525(514-541)$ & $531(523-546)$ & S (0.0001) \\
Mean deviation (db) & $-0.73 \pm 0.93$ & $-0.06 \pm 0.77$ & S (0.0001) \\
Pattern standard deviation $(\mathrm{db})$ & $1.87 \pm 0.52$ & $1.84 \pm 0.28$ & \\
\hline
\end{tabular}

First Group of ocular hypertension patients under topical treatment. Second group of healthy individuals. Data reported as number of mean \pm SD or median with interquartile range. Probability Mann-Whitney U test for nonparametric data. Independent sample t-test for parametric data. Significance $P \leq 0.05$. NA non applicable.

The median total score of QoL questionnaire of OHT group was 84.54 (interquartile range 77.45 - 91.14) while the total score of the healthy group was significantly higher with a median of 99.3 (interquartile range 97.91 - 100; $P=0.0001$ ). Table 2 presents the results of scores for all the subscales and the total score of NEI-VFQ questionnaire of the two groups. The median score for the general vision of OHT patients under topical medication was 75 with interquartile range between 50 and 75 lower than the healthy group $(P=0.0001)$. The median scores for almost all the subscales of the first group were significantly lower than those of the second one $(P=0.0001)$.

Males of the first group presented significantly lower median total score than the females of the same group (81.41 and 87.32 respectively, $P=0.001$ ). Table 3 presents the scores of NEI-VFQ 25 of OHT patients according to their gender. The subscales of general health, general vision, ocular pain near activities, role difficulty and peripheral vision were significantly worst for OHT men than for OHT women under topical treatment $(P<$ $0.05)$.

Ocular hypertension patients of the first group that used one medication for treatment, presented a median total score of QoL questionnaire of 89.23 with interquartile range between 85.24 and 94.79, that is significantly higher from the median total score of the patients that used two medications (81.24, interquartile range between 77.45 and 85.32, $P=0.0001$ ) or three medications (72.91 and with interquartile range between 70.39 and 77.16, $P=0.0001)$. The total score of OHT patients that used two medication were also significantly higher than the patients that used three drugs $(P=0.004)$. Table 4 presents the scores of all the subscales of NEI-VFQ 25 for OHT patients that used one, two or three medications respectively. For all the categories the OHT patients with one topical medication, had significantly higher scores than the other patients $(P<0.05)$.

Best corrected visual acuity presents a significant correlation with the total score $(r=0.237, P=0.009)$, the general health $(r=0.327, P=0.0001)$ and the near activities $(r=0.296, P=0.001)$ of QoL questionnaire of OHT patients. The intraocular correlates also significantly with most subscales of OHT patients. Instead daily number of medications does not present significant correlations with any of the subscales of NEI-VFQ 25 ( $P$ > 0.05). PSD is the global index of the visual fields that better correlates with the QoL of OHT patients. Table 5 presents the correlations of the clinical characteristics of OHT patients' group with the subscales and the total score of the questionnaire.

Table 6 presents the results of the multivariate linear regression analysis for all the subscales of OHT patients. The clinical characteristic "daily number of medications" represents the index that influences almost all subscales and the total score $(-7.775, P=0.0001)$ of the questionnaire $(P<0.05)$. The near activities, role difficulty and total score are the subscales better explained by the clinical characteristics of OHT patients group $\left(R^{2}=\right.$ $0.279,0.539$ and 0.383 respectively). 
Table 2. Scores of the questionnaire (NEI-VFQ 25) for the two groups.

\begin{tabular}{|c|c|c|c|c|c|}
\hline & \multicolumn{2}{|c|}{$1^{\text {st }}$ Group (OHT under treatment) } & \multicolumn{2}{|c|}{$2^{\text {nd }}$ Group (Healthy Group) } & \multirow{2}{*}{$\begin{array}{c}\text { Probability } \\
\text { (Mann-Whitney } \\
\text { U test) }\end{array}$} \\
\hline & Median & (Interquartile range) & Median & (Interquartile range) & \\
\hline 1) General health & 75 & $50-75$ & 100 & $75-100$ & $P<0.0001$ \\
\hline 2) General vision & 75 & $50-75$ & 100 & $100-100$ & $P<0.0001$ \\
\hline 3) Ophthalmic pain & 75 & $62.5-87.5$ & 100 & $100-100$ & $P<0.0001$ \\
\hline 4) Near activities & 87.5 & $66.6-100$ & 100 & $100-100$ & $P<0.0001$ \\
\hline 5) Distance vision & 91.63 & $77.08-100$ & 100 & $100-100$ & $P<0.0001$ \\
\hline 6) Social activities & 100 & $100-100$ & 100 & $100-100$ & $P<0.0001$ \\
\hline 7) Mental health & 75 & $62.75-85.93$ & 100 & $93.75-100$ & $P<0.0001$ \\
\hline 8) Role Difficulty & 100 & $75-100$ & 100 & $100-100$ & $P<0.0001$ \\
\hline 9) Dependency & 91.67 & $83.33-100$ & 100 & $100-100$ & $P<0.0001$ \\
\hline 10) Driving & 100 & $83.33-100$ & 100 & $100-100$ & $P<0.0001$ \\
\hline 11) Color vision & 100 & $100-100$ & 100 & $100-100$ & $P<0.0001$ \\
\hline 12) Peripheral vision & 100 & $100-100$ & 100 & $100-100$ & $P<0.0001$ \\
\hline Total score & 84.54 & $77.45-91.14$ & 99.3 & $97.91-100$ & $P<0.0001$ \\
\hline
\end{tabular}

Significance $P \leq 0.05$.

Table 3. Scores of the questionnaire (NEI-VFQ 25) of the ocular hypertension group according to their sex.

\begin{tabular}{lccc}
\hline \multicolumn{1}{c}{ VFQ-25 category } & Female & Male & Probability (Mann-Whitney U test) \\
\hline 1) General health & $75(50-75)$ & $50(25-75)$ & $P=0.044$ \\
2) General vision & $75(75-100)$ & $75(50-87.5)$ & $P=0.001$ \\
3) Ophthalmic pain & $87.5(62.5-100)$ & $75(50-87.5)$ & $P=0.013$ \\
4) Near activities & $91.66(83.33-100)$ & $70.8(58.33-83.33)$ & $P=0.0001$ \\
5) Distance vision & $91.63(83.33-100)$ & $95.8(75-100)$ & $P=0.707$ \\
6) Social activities & $100(100-100)$ & $100(100-100)$ & $P=0.189$ \\
7) Mental health & $75(62.75-81.25)$ & $75(50-87.5)$ & $P=0.621$ \\
8) Role difficulty & $100(75-100)$ & $75(62.5-100)$ & $P=0.0001$ \\
9) Dependency & $91.66(83.33-100)$ & $91.66(83.33-100)$ & $P=0.271$ \\
10) Driving & $100(83.33-100)$ & $91.66(83.33-100)$ & $P=0.225$ \\
11) Color vision & $100(100-100)$ & $100(100-100)$ & $P=0.614$ \\
12) Peripheral vision & $100(100-100)$ & $100(75-100)$ & $P=0.009$ \\
Total score & $87.32(82.07-93.09)$ & $81.41(72.39-85.59)$ & $P=0.001$ \\
\hline
\end{tabular}

Data reported as number of median (interquartile range). Mann Whitney $\mathrm{U}$ test; significance $P \leq 0.05$.

\section{Discussion}

Glaucoma decreases the quality of life for different reasons that include the diagnosis itself, the perimetric functional loss, the treatment itself, its side effects and costs [5]. Previous studies evaluated the relation between glaucoma, treatment, and health-related quality of life [22] including patients with established visual field defects [23]. Instead QoL of ocular hypertension patients under treatment has not been still estimated. 
Table 4. Scores of the questionnaire (NEI-VFQ 25) of the ocular hypertension group according to the number of medication used.

\begin{tabular}{|c|c|c|c|}
\hline VFQ-25 category & 1 medication & 2 medications & 3 medications \\
\hline 1) General health & $\begin{array}{c}75(50-81.25) \\
(0.003) 1-2 \\
(0.0001) 1-3\end{array}$ & $\begin{array}{c}50(25-75) \\
(0.003) 1-2 \\
(0.29) 2-3\end{array}$ & $\begin{array}{c}50(25-56.25) \\
(0.0001) 1-3 \\
(0.29) 2-3\end{array}$ \\
\hline 2) General vision & $\begin{array}{l}75(75-100) \\
(0.0001) 1-2 \\
(0.0001) 1-3\end{array}$ & $\begin{array}{l}75(50-75) \\
(0.003) 1-2 \\
(0.001) 2-3\end{array}$ & $\begin{array}{c}50(50-56.25) \\
(0.0001) 1-3 \\
(0.001) 2-3\end{array}$ \\
\hline 3) Ophthalmic pain & $\begin{array}{c}87.5(75-100) \\
(0.001) 1-2 \\
(0.004) 1-3\end{array}$ & $\begin{array}{c}75(62.5-87.5) \\
(0.001) 1-2 \\
(0.36) 2-3\end{array}$ & $\begin{array}{l}62.5(50-81.25) \\
\quad(0.004) 1-3 \\
(0.36) 2-3\end{array}$ \\
\hline 4) Near activities & $\begin{array}{c}91.66(83.33-100) \\
(0.017) 1-2 \\
(0.0001) 1-3\end{array}$ & $\begin{array}{c}83.33(66.6-91.66) \\
(0.017) 1-2 \\
(0.001) 2-3\end{array}$ & $\begin{array}{c}58.33(58.33-75) \\
(0.0001) 1-3 \\
(0.001) 2-3\end{array}$ \\
\hline 5) Distance vision & $\begin{array}{c}91.66(81.24-100) \\
(0.622) 1-2 \\
(0.187) 1-3\end{array}$ & $\begin{array}{c}91.66(83.33-100) \\
(0.622) 1-2 \\
(0.046) 2-3\end{array}$ & $\begin{array}{c}75(75-100) \\
(0.187) 1-3 \\
(0.046) 2-3\end{array}$ \\
\hline 6) Social activities & $\begin{array}{c}100(100-100) \\
(0.243) 1-2 \\
(0.77) 1-3\end{array}$ & $\begin{array}{c}100(100-100) \\
(0.243) 1-2 \\
(0.297) 2-3\end{array}$ & $\begin{array}{c}100(100-100) \\
(0.77) 1-3 \\
(0.297) 2-3\end{array}$ \\
\hline 7) Mental health & $\begin{array}{l}81.25(75-87.5) \\
\quad(0.0001) 1-2 \\
(0.042) 1-3\end{array}$ & $\begin{array}{c}68.75(62.5-81.25) \\
(0.0001) 1-2 \\
(0.66) 2-3\end{array}$ & $\begin{array}{l}75(50-75) \\
(0.042) 1-3 \\
(0.66) 2-3\end{array}$ \\
\hline 8) Role difficulty & $\begin{array}{c}100(100-100) \\
(0.0001) 1-2 \\
(0.0001) 1-3\end{array}$ & $\begin{array}{l}75(75-100) \\
(0.0001) 1-2 \\
(0.0001) 2-3\end{array}$ & $\begin{array}{l}75(62.5-75) \\
(0.0001) 1-3 \\
(0.0001) 2-3\end{array}$ \\
\hline 9) Dependency & $\begin{array}{c}100(89.57-100) \\
(0.0001) 1-2 \\
(0.001) 1-3\end{array}$ & $\begin{array}{c}91.66(66.66-91.66) \\
(0.0001) 1-2 \\
(0.367) 2-3\end{array}$ & $\begin{array}{c}83.33(58.33-93.74) \\
(0.001) 1-3 \\
(0.367) 2-3\end{array}$ \\
\hline 10) Driving & $\begin{array}{c}100(100-100) \\
(0.001) 1-2 \\
(0.0001) 1-3\end{array}$ & $\begin{array}{c}83.33(83.33-100) \\
(0.001) 1-2 \\
(0.041) 2-3\end{array}$ & $\begin{array}{c}83.33(75-87.49) \\
(0.0001) 1-3 \\
(0.041) 2-3\end{array}$ \\
\hline 11) Color vision & $\begin{array}{c}100(100-100) \\
(0.0001) 1-2 \\
(0.0001) 1-3\end{array}$ & $\begin{array}{c}100(75-100) \\
(0.0001) 1-2 \\
(0.682) 2-3\end{array}$ & $\begin{array}{c}100(93.75-100) \\
(0.0001) 1-3 \\
(0.682) 2-3\end{array}$ \\
\hline 12) Peripheral vision & $\begin{array}{c}100(100-100) \\
(0.091) 1-2 \\
(0.0001) 1-3\end{array}$ & $\begin{array}{c}100(75-100) \\
(0.091) 1-2 \\
(0.002) 2-3\end{array}$ & $\begin{array}{c}75(75-100) \\
(0.0001) 1-3 \\
(0.002) 2-3\end{array}$ \\
\hline Total score & $\begin{array}{c}89.23(85.24-94.79) \\
(0.0001) 1-2 \\
(0.0001) 1-3\end{array}$ & $\begin{array}{c}81.24(77.45-85.32) \\
(0.0001) 1-2 \\
(0.004) 2-3\end{array}$ & $\begin{array}{c}72.91(70.39-77.16) \\
(0.0001) 1-3 \\
(0.004) 2-3\end{array}$ \\
\hline
\end{tabular}

Data reported as number of median (interquartile range). Probability between patients that use 1 medication and 2 medications (1-2). Probability between patients that use 1 medication and 3 medications (1-3). Probability between patients that use 2 medication and 3 medications (2-3). Mann Whitney $U$ test; significance $P \leq 0.05$.

The present study is focused on the quality of life related to vision of OHT patients that use topical medications with physiological achromatic visual fields and found a declined QoL when compared to that of healthy persons. For almost all of the qualitative subscales and the total score of QoL, OHT patients had worst results. This finding is in accordance with other studies assessing QoL of glaucomatous patients [24] [25]. Wolfram and other found that QoL impairment in glaucoma patients lies between OHT/early POAG versus moderate/severe POAG [11]. QoL in these two groups, OHT under treatment and glaucomatous patients, probably is in the same way compromised but further studies will probably explain better this relationship and clarify the impact that the different factors have on them. 
Table 5. Spearman correlation between the Subscale Scores of the questionnaire NEI-VFQ 25 and the clinical Indices of the ocular hypertension patients under topical treatment.

\begin{tabular}{|c|c|c|c|c|c|c|c|c|}
\hline VFQ-25 category & Age & $\begin{array}{l}\text { Best corrected } \\
\text { visual acuity }\end{array}$ & $\begin{array}{l}\text { Intraocular } \\
\text { pressure }\end{array}$ & $\begin{array}{l}\text { Cup to } \\
\text { disc ratio }\end{array}$ & $\begin{array}{c}\text { Central corneal } \\
\text { thickness }\end{array}$ & $\begin{array}{c}\text { Mean } \\
\text { deviation }\end{array}$ & $\begin{array}{l}\text { Pattern standard } \\
\text { deviation }\end{array}$ & $\begin{array}{l}\text { Daily number } \\
\text { of medications }\end{array}$ \\
\hline 1) General health (S) & $\begin{array}{c}-0.129 \\
(0.16)\end{array}$ & $\begin{array}{l}0.327++ \\
(0.0001)\end{array}$ & $\begin{array}{l}0.196+ \\
(0.032)\end{array}$ & $\begin{array}{l}-0.15 \\
(0.102)\end{array}$ & $\begin{array}{c}0.1 \\
(0.277)\end{array}$ & $\begin{array}{l}-0.089 \\
(0.331)\end{array}$ & $\begin{array}{l}-0.010 \\
(0.913)\end{array}$ & $\begin{array}{l}-0.089 \\
(0.331)\end{array}$ \\
\hline 2) General vision (S) & $\begin{array}{l}-0.012 \\
(0.901)\end{array}$ & $\begin{array}{c}0.162 \\
(0.077)\end{array}$ & $\begin{array}{l}0.199+ \\
(0.029)\end{array}$ & $\begin{array}{l}-0.16 \\
(0.081)\end{array}$ & $\begin{array}{c}0.016 \\
(0.861)\end{array}$ & $\begin{array}{l}-0.04 \\
(0.663)\end{array}$ & $\begin{array}{c}-0.224+ \\
(0.014)\end{array}$ & $\begin{array}{l}-0.040 \\
(0.663)\end{array}$ \\
\hline 3) Ophthalmic pain (S) & $\begin{array}{c}0.09 \\
(0.328)\end{array}$ & $\begin{array}{c}0.142 \\
(0.122)\end{array}$ & $\begin{array}{c}-0.248)++ \\
(0.006)\end{array}$ & $\begin{array}{c}-0.198+ \\
(0.03)\end{array}$ & $\begin{array}{c}0.068 \\
(0.458)\end{array}$ & $\begin{array}{l}-0.077 \\
(0.403)\end{array}$ & $\begin{array}{l}-0.017 \\
(0.858)\end{array}$ & $\begin{array}{l}-0.077 \\
(0.403)\end{array}$ \\
\hline 4) Near activities (S) & $\begin{array}{c}-0.183^{+} \\
(\mathbf{0 . 0 4 5 )}\end{array}$ & $\begin{array}{c}0.296++ \\
(0.001)\end{array}$ & $\begin{array}{c}0.296++ \\
(0.001)\end{array}$ & $\begin{array}{c}-0.210+ \\
(0.021)\end{array}$ & $\begin{array}{c}0.278++ \\
(0.002)\end{array}$ & $\begin{array}{c}0.049 \\
(0.593)\end{array}$ & $\begin{array}{l}-0.107 \\
(0.246)\end{array}$ & $\begin{array}{c}0.049 \\
(0.593)\end{array}$ \\
\hline 5) Distance vision (S) & $\begin{array}{c}0.094 \\
(0.309)\end{array}$ & $\begin{array}{l}-0.029 \\
(0.751)\end{array}$ & $\begin{array}{c}0.130 \\
(0.158)\end{array}$ & $\begin{array}{l}-0.034 \\
(0.712)\end{array}$ & $\begin{array}{l}-0.149 \\
(0.104)\end{array}$ & $\begin{array}{l}-0.074 \\
(0.421)\end{array}$ & $\begin{array}{l}0 .-124 \\
(0.179)\end{array}$ & $\begin{array}{l}-0.074 \\
(0.421)\end{array}$ \\
\hline 6) Social activities (S) & $\begin{array}{c}0.101 \\
(0.272)\end{array}$ & $\begin{array}{c}0.084 \\
(0.359)\end{array}$ & $\begin{array}{c}-0.243++ \\
(0.008)\end{array}$ & $\begin{array}{l}-0.167 \\
(0.068)\end{array}$ & $\begin{array}{c}0.065 \\
(0.483)\end{array}$ & $\begin{array}{l}-0.047 \\
(0.612)\end{array}$ & $\begin{array}{l}-0.080 \\
(0.383)\end{array}$ & $\begin{array}{l}-0.04 \\
(0.612)\end{array}$ \\
\hline 7) Mental health (S) & $\begin{array}{c}0.055 \\
(0.552)\end{array}$ & $\begin{array}{c}0.117 \\
(0.202)\end{array}$ & $\begin{array}{c}0.078 \\
(0.399)\end{array}$ & $\begin{array}{c}0.036 \\
(0.693)\end{array}$ & $\begin{array}{c}0.08 \\
(0.383)\end{array}$ & $\begin{array}{l}-0.059 \\
(0.521)\end{array}$ & $\begin{array}{l}-0.085 \\
(0.354)\end{array}$ & $\begin{array}{l}-0.059 \\
(0.521)\end{array}$ \\
\hline 8) Role difficulty (S) & $\begin{array}{l}0.386++ \\
(0.0001)\end{array}$ & $\begin{array}{l}-0.018 \\
(0.841)\end{array}$ & $\begin{array}{c}0.072 \\
(0.437)\end{array}$ & $\begin{array}{l}-0.114 \\
(0.213)\end{array}$ & $\begin{array}{c}0.066 \\
(0.474)\end{array}$ & $\begin{array}{l}-0.009 \\
(0.920)\end{array}$ & $\begin{array}{c}0.003 \\
(0.976)\end{array}$ & $\begin{array}{c}-0.009 \\
(0.92)\end{array}$ \\
\hline 9) Dependency (S) & $\begin{array}{c}0.038 \\
(0.684)\end{array}$ & $\begin{array}{c}0.159 \\
(0.083)\end{array}$ & $\begin{array}{l}0.199+ \\
(0.029)\end{array}$ & $\begin{array}{l}0.073 \\
(0.43)\end{array}$ & $\begin{array}{l}-0.019 \\
(0.841)\end{array}$ & $\begin{array}{l}-0.163 \\
(0.075)\end{array}$ & $\begin{array}{c}-0.116 \\
(-0.116)\end{array}$ & $\begin{array}{l}-0.163 \\
(0.075)\end{array}$ \\
\hline 10) Driving (S) & $\begin{array}{l}-0.041 \\
(0.653)\end{array}$ & $\begin{array}{c}0.174 \\
(0.157)\end{array}$ & $\begin{array}{c}0.006 \\
(0.947)\end{array}$ & $\begin{array}{l}-0.054 \\
(0.558)\end{array}$ & $\begin{array}{l}0.077 \\
(0.4)\end{array}$ & $\begin{array}{l}-0.014 \\
(0.879)\end{array}$ & $\begin{array}{l}-0.169 \\
(0.065)\end{array}$ & $\begin{array}{l}-0.014 \\
(0.879)\end{array}$ \\
\hline 11) Color vision (S) & $\begin{array}{l}-0.057 \\
(0.538)\end{array}$ & $\begin{array}{c}0.179 \\
(0.051)\end{array}$ & $\begin{array}{l}-0.051 \\
(0.584)\end{array}$ & $\begin{array}{c}0.016 \\
(0.866)\end{array}$ & $\begin{array}{c}0.147 \\
(0.110)\end{array}$ & $\begin{array}{l}-0.028 \\
(0.765)\end{array}$ & $\begin{array}{c}-0.258++ \\
(0.004)\end{array}$ & $\begin{array}{l}-0.028 \\
(0.765)\end{array}$ \\
\hline 12) Peripheral vision (S) & $\begin{array}{c}0.037 \\
(0.689)\end{array}$ & $\begin{array}{c}0.153 \\
(0.095)\end{array}$ & $\begin{array}{l}0.231+ \\
(0.019)\end{array}$ & $\begin{array}{c}-0.162 \\
(0.77)\end{array}$ & $\begin{array}{c}0.109 \\
(0.237)\end{array}$ & $\begin{array}{l}-0.126 \\
(0.172)\end{array}$ & $\begin{array}{l}-0.095 \\
(0.302)\end{array}$ & $\begin{array}{l}-0.121 \\
(0.172)\end{array}$ \\
\hline Total score (S) & $\begin{array}{c}0.133 \\
(0.149)\end{array}$ & $\begin{array}{c}0.237++ \\
(0.009)\end{array}$ & $\begin{array}{c}0.151 \\
(0.1)\end{array}$ & $\begin{array}{l}-0.163 \\
(0.076)\end{array}$ & $\begin{array}{c}0.160 \\
(0.081)\end{array}$ & $\begin{array}{l}-0.046 \\
(0.619)\end{array}$ & $\begin{array}{l}-0.087 \\
(0.345)\end{array}$ & $\begin{array}{l}-0.046 \\
(0.619)\end{array}$ \\
\hline
\end{tabular}

Significance (S): $++P \leq 0.01,+P \leq 0.05$.

Males with preperimetric glaucoma under treatment presented worst QoL respect to women of the same group. This finding is in contrast with the study of Labiris and other [26] for pseudoexfoliative glaucoma patients. Tastan and other also found that depression and quality of life were decreased in women with glaucoma [27]. Instead in accordance to our study Odberg and collogues found that in patients with glaucoma, the women were in general more dissatisfied than the men [28].

Another finding of the study is that as the number of medications used by OHT patients increases their quality of life decreases. Skalicky and other also found that in patients with increasing glaucoma severity QoL is poorer as there is a higher probability of ocular surface disease because of benzalkonium chloride exposure [29]. The number of medications used by OHT patients is likely to be an important factor with negative impact on QoL ( $P$ $=0.0001$ ) and according to the results of the regression analysis of the study is more sensitive than the other clinical characteristics. This finding is also in accordance with other studies focusing in glaucoma patients [26].

Best corrected visual acuity and intraocular pressure are both sensitive indices of QoL in OHT patients and possibly their impairment can explain the change of the qualitative subscales of the quality of life in preperimetric glaucoma group of patients. Previous studies in normal tension glaucoma patients also found the same impact of BCVA and IOP in QoL [25]. The age, CD ratio and CCT can affect different characteristics of QoL. PSD has been identified as the visual fields global index that correlates significantly with QoL. Nelson and other 
Table 6. Multivariate linear regression analysis of the quality of life subscales' of ocular hypertension patients group.

\begin{tabular}{|c|c|c|c|c|c|c|c|c|c|}
\hline VFQ-25 category & $\begin{array}{l}\text { Adjusted } \\
\text { R Square }\end{array}$ & $\begin{array}{l}\text { B coef. } \\
\text { Age (S) }\end{array}$ & $\begin{array}{c}\text { B coef. } \\
\text { BCVA (S) }\end{array}$ & $\begin{array}{l}\text { B coef. } \\
\text { IOP (S) }\end{array}$ & $\begin{array}{c}\text { B coef. } \\
\text { N.med (S) }\end{array}$ & $\begin{array}{l}\text { B coef } \\
\text { CD (S) }\end{array}$ & $\begin{array}{l}\text { B coef. } \\
\text { CCT (1) }\end{array}$ & $\begin{array}{l}\text { B coef. } \\
\text { MD (S) }\end{array}$ & $\begin{array}{l}\text { B coef. } \\
\text { PSD (S) }\end{array}$ \\
\hline 1) General health (S) & 0.205 & NS & $\begin{array}{c}14.163++ \\
(0.002)\end{array}$ & NS & $\begin{array}{c}-11.087++ \\
(0.001)\end{array}$ & NS & NS & NS & NS \\
\hline 2) General vision (S) & 0.279 & NS & NS & NS & $\begin{array}{c}-15.522++ \\
(0.0001)\end{array}$ & NS & $\begin{array}{c}-0.256+ \\
(0.001)\end{array}$ & NS & NS \\
\hline 3) Ophthalmic pain (S) & 0.266 & NS & NS & $\begin{array}{c}-5.684++ \\
(0.0001)\end{array}$ & $\begin{array}{c}-13.348++ \\
(0.0001)\end{array}$ & NS & NS & NS & NS \\
\hline 4) Near activities (S) & 0.279 & $\begin{array}{c}-0.851++ \\
\mathbf{( 0 . 0 0 1 )}\end{array}$ & $\begin{array}{l}6.158+ \\
(0.041)\end{array}$ & $\begin{array}{l}2.423+ \\
(0.043)\end{array}$ & $\begin{array}{c}-6.038+ \\
(0.015)\end{array}$ & $\begin{array}{c}-30.179+ \\
\mathbf{( 0 . 0 3 9 )}\end{array}$ & NS & NS & NS \\
\hline 5) Distance vision (S) & NA & NS & NS & NS & NS & NS & NS & NS & NS \\
\hline 6) Social activities (S) & 0.07 & NS & NS & $\begin{array}{c}-0.807++ \\
(0.008)\end{array}$ & NS & $\begin{array}{c}-8.542+ \\
(0.027)\end{array}$ & NS & NS & NS \\
\hline 7) Mental health (S) & 0.92 & NS & NS & NS & $\begin{array}{c}-6.441++ \\
(0.001)\end{array}$ & NS & NS & NS & NS \\
\hline 8) Role difficulty (S) & 0.539 & $\begin{array}{l}1.023++ \\
(0.0001)\end{array}$ & $\begin{array}{l}-4.64+ \\
(0.019)\end{array}$ & $\begin{array}{c}-2.260++ \\
(0.001)\end{array}$ & $\begin{array}{c}-16.491++ \\
(0.0001)\end{array}$ & NS & $\begin{array}{c}-0.114+ \\
(\mathbf{0 . 0 3 4})\end{array}$ & NS & NS \\
\hline 9) Dependency (S) & 0.293 & NS & NS & NS & $\begin{array}{c}-10.600++ \\
(0.0001)\end{array}$ & NS & $\begin{array}{c}-0.184++ \\
(\mathbf{0 . 0 0 1 )}\end{array}$ & NS & NS \\
\hline 10) Driving (S) & 0.231 & NS & NS & $\begin{array}{c}-1.496+ \\
(0.017)\end{array}$ & $\begin{array}{c}-6.774++ \\
(0.0001)\end{array}$ & NS & NS & NS & $\begin{array}{c}-3.39+ \\
(0.03)\end{array}$ \\
\hline 11) Color vision (S) & 0.166 & NS & NS & $\begin{array}{c}-1.248+ \\
(0.026)\end{array}$ & $\begin{array}{c}-4.319++ \\
(0.0001)\end{array}$ & NS & NS & NS & $\begin{array}{c}-4.112++ \\
(0.004)\end{array}$ \\
\hline 12) Peripheral vision (S) & 0.162 & NS & NS & NS & $\begin{array}{c}-6.915++ \\
(0.0001)\end{array}$ & NS & NS & NS & NS \\
\hline Total score (S) & 0.383 & NS & NS & NS & $\begin{array}{c}-7.775++ \\
(0.0001)\end{array}$ & NS & NS & NS & NS \\
\hline
\end{tabular}

Significance (S): $++P \leq .01,+P \leq .05$. Abbreviations B coef.: B coefficient, BCVA: best corrected visual acuity, IOP: intraocular pressure, $\mathrm{N}$ med: number of medications, CD: cup to disk ratio, CCT: central corneal thickness, MD: mean deviation, PSD: pattern standard deviation. NS non significant. NA non applicable.

found that MD significantly related with QoL of glaucoma patients [30]. On the other hand Iester and colleagues found that QoL of glaucoma patients was significantly correlated with both MD and PSD [31]. Further studies need to be computed to clarify if the visual fields global indices, MD and PSD, have different impact on OHT and glaucoma patients.

A limitation of this study is the small number of OHT patients under treatment with different medications and/or different doses of medications. This will help to understand if a specific glaucoma medication is better correlated with QoL than another. Another limit is that a group of glaucoma patients was not included in the study and because of that no obvious comparisons can be computed between this group and a group of OHT patients. Further studies need to be done to clarify better these aspects.

\section{Conclusion}

In conclusion, the quality of life related to vision of OHT patients under topical treatment is significantly decreased than that of healthy persons. Male sex and the number of medications affect QoL more. The best corrected visual acuity and intraocular pressure represent the clinical findings that best correlate with several qua- 
litative aspects of QoL. The pattern standard deviation is a significant index that correlates well with the quality of life of OHT patients.

\section{Conflicts of Interest}

None of the authors has conflict of interest with the submission.

\section{Financial Support}

No financial support was received for this submission.

\section{Meeting Presentation}

The paper has not been presented.

\section{Informed Consent}

The study was performed following all the guidelines for experimental investigations required by the Institutional Review Board or Ethics Committee of which all authors are affiliated. Informed consent was obtained from all subjects.

\section{References}

[1] Cowan Jr., C.L., Worthen, D.M., Mason, R.P. and Anduze, A.L. (1988) Glaucoma in Blacks. Acta Ophthalmologica, 106, 738-739. http://dx.doi.org/10.1001/archopht.1988.01060130808027

[2] Cate, H., Bhattacharya, D., Clark, A., Holland, R. and Broadway, D.C. (2013) Patterns of Adherence Behaviour for Patients with Glaucoma. Eye, 27, 545-553. http://dx.doi.org/10.1038/eye.2012.294

[3] Odberg, T. (1993) Visual Field Prognosis in Early Glaucoma. A Long-Term Clinical Follow-Up. Acta Ophthalmologica, 71, 721-726. http://dx.doi.org/10.1111/j.1755-3768.1993.tb08590.x

[4] Schwartz, G.F. and Quigley, H.A. (2008) Adherence and Persistence with Glaucoma Therapy. Survey of Ophthalmology, 53, S57-S68. http://dx.doi.org/10.1016/j.survophthal.2008.08.002

[5] Iester, M. and Zingirian, M. (2002) Quality of Life in Patients with Early, Moderate and Advanced Glaucoma. Eye, 16, 44-49. http://dx.doi.org/10.1038/sj.eye.6700036

[6] Weinstein, J.M., Duckrow, R.B., Beard, D. and Brennan, R.W. (1983) Regional Optic Nerve Blood Flow and Its Autoregulation. Investigative Ophthalmology \& Visual Science, 24, 1559-1565.

[7] Mills, R.P., Janz, N.K., Wren, P.A. and Guire, K.E. (2001) Correlation of Visual Field with Quality-of-Life Measures at Diagnosis in the Collaborative Initial Glaucoma Treatment Study (CIGTS). Journal of Glaucoma, 10, 192-198. http://dx.doi.org/10.1097/00061198-200106000-00008

[8] Nelson, P., Aspinall, P., Papasouliotis, O., Worton, B. and O’Brien, C. (2003) Quality of Life in Glaucoma and Its Relationship with Visual Function. Journal of Glaucoma, 12, 139-150. http://dx.doi.org/10.1097/00061198-200304000-00009

[9] Watson, P.G. and Grierson, I. (1981) The Place of Trabeculectomy in the Treatment of Glaucoma. Ophthalmology, 88, 175-196. http://dx.doi.org/10.1016/S0161-6420(81)35051-9

[10] Sleath, B., Robin, A.L., Covert, D., Byrd, J.E., Tudor, G. and Svarstad, B. (2006) Patient-Reported Behavior and Problems in Using Glaucoma Medications. Ophthalmology, 113, 431-436. http://dx.doi.org/10.1016/j.ophtha.2005.10.034

[11] Wolfram, C., Lorenz, K., Breitscheidel, L., Verboven, Y. and Pfeiffer, N. (2013) Health- and Vision-Related Quality of Life in Patients with Ocular Hypertension or Primary Open-Angle Glaucoma. Ophthalmologica, 229, 227-234. http://dx.doi.org/10.1159/000350553

[12] Shaffer, R. (1977) “Glaucoma Suspect” or “Ocular Hypertension”. Archives of Ophthalmology, 95, 588. http://dx.doi.org/10.1001/archopht.1977.04450040054004

[13] Asaoka, R., Iwase, A., Hirasawa, K., Murata, H. and Araie, M.I. (2014) Identifying "Preperimetric” Glaucoma in Standard Automated Perimetry Visual Fields. Investigative Ophthalmology \& Visual Science, 55, 7814-7820. http://dx.doi.org/10.1167/iovs.14-15120

[14] Mangione, C.M., Lee, P.P., Gutierrez, P.R., Spritzer, K., Berry, S. and Hays, R.D. (2001) Development of the 25-Item National Eye Institute Visual Function Questionnaire. Archives of Ophthalmology, 119, 1050-1058. http://dx.doi.org/10.1001/archopht.119.7.1050 
[15] Wren, P.A., Musch, D.C., Janz, N.K., Niziol, L.M., Guire, K.E. and Gillespie, B.W., CIGTS Study Group (2009) Contrasting the Use of 2 Vision-Specific Quality of Life Questionnaires in Subjects with Open-Angle Glaucoma. Journal of Glaucoma, 18, 403-411. http://dx.doi.org/10.1097/IJG.0b013e3181879e63

[16] Lisboa, R., Chun, Y.S., Zangwill, L.M., Weinreb, R.N., Rosen, P.N., Liebmann, J.M., Girkin, C.A. and Medeiros, F.A. (2013) Association between Rates of Binocular Visual Field Loss and Vision-Related Quality of Life in Patients with Glaucoma. JAMA Ophthalmology, 131, 486-494. http://dx.doi.org/10.1001/jamaophthalmol.2013.2602

[17] Sawada, H., Fukuchi, T. and Abe, H. (2011) Evaluation of the Relationship between Quality of Vision and the Visual Function Index in Japanese Glaucoma Patients. Graefe's Archive for Clinical and Experimental Ophthalmology, 249, 1721-1727. http://dx.doi.org/10.1007/s00417-011-1779-5

[18] Mangione, C.M., Lee, P.P., Pitts, J., Gutierrez, P., Berry, S. and Hays, R.D. (1998) Psychometric Properties of the National Eye Institute Visual Function Questionnaire (NEI-VFQ). Archives of Ophthalmology, 116, 1496-1504. http://dx.doi.org/10.1001/archopht.116.11.1496

[19] Mangione, C.M., Berry, S., Spritzer, K., Janz, N.K., Klein, R., Owsley, C. and Lee, P.P. (1998) Identifying the Content Area for the 51-Item National Eye Institute Vision Function Questionnaire: Results from Focus Groups with Visually Impaired Persons. Archives of Ophthalmology, 116, 227-233. http://dx.doi.org/10.1001/archopht.116.2.227

[20] Cole, S.R., Beck, R.W., Moke, P.S., Gal, R.L. and Long, D.T. (2000) The National Eye Institute Visual Function Questionnaire: Experience of the ONTT. Optic Neuritis Treatment Trial. Investigative Ophthalmology \& Visual Science, 41, 1017-1021.

[21] Laboratory of Experimental Ophthalmology of Aristotle University (2000) Greek Language Translation of the National Eye Institute Visual Function Questionnaire. Aristotle University, Thessaloniki. Http://www.rand.org/content/dam/rand/www/external/health/surveys_tools/vfq/vfq25survey_greek.pdf

[22] Massof, R.W. and Fletcher, D.C. (2001) Evaluation of the NEI Visual Functioning Questionnaire as an Interval Measure of Visual Ability in Low Vision. Vision Research, 41, 397-413. http://dx.doi.org/10.1016/S0042-6989(00)00249-2

[23] Yamagishio, K., Keiji, Y., Kimura, T., Yamabayashi, S. and Katsushima, H. (2009) Quality of Life Evaluation in Elderly Normal Tension Glaucoma Patients Using the Japanese Version of VFQ-25. Nippon Ganka Gakkai Zasshi, 113, 964-971.

[24] Richman, J., Lorenzana, L.L., Lankaranian, D., Dugar, J., Mayer, J.R., Wizov, S.S. and Spaeth, G.L. (2010) Relationships in Glaucoma Patients between Standard Vision Tests, Quality of Life, and Ability to Perform Daily Activities. Ophthalmic Epidemiology, 17, 144-151. http://dx.doi.org/10.3109/09286581003734878

[25] Hyman, L.G., Komaroff, E., Heijl, A., Bengtsson, B. and Leske, M.C., Early Manifest Glaucoma Trial Group (2005) Treatment and Vision-Related Quality of Life in the Early Manifest Glaucoma Trial. Ophthalmology, 112, 1505-1513. http://dx.doi.org/10.1016/j.ophtha.2005.03.028

[26] Labiris, G., Katsanos, A., Fanariotis, M., Zacharaki, F., Chatzoulis, D. and Kozobolis, V.P. (2010) Vision-Specific Quality of Life in Greek Glaucoma Patients. Journal of Glaucoma, 19, 39-43. http://dx.doi.org/10.1097/IJG.0b013e31819d5cf7

[27] Tastan, S., Iyigun, E., Bayer, A. and Acikel, C. (2010) Anxiety, Depression, and Quality of Life in Turkish Patients with Glaucoma. Psychological Reports, 106, 343-357. http://dx.doi.org/10.2466/pr0.106.2.343-357

[28] Odberg, T., Jakobsen, J.E., Hultgren, S.J. and Halseide, R. (2001) The Impact of Glaucoma on the Quality of Life of Patients in Norway. I. Results from a Self-Administered Questionnaire. Acta Ophthalmologica Scandinavica, 79, 116120. http://dx.doi.org/10.1034/j.1600-0420.2001.079002116.x

[29] Skalicky, S.E., Goldberg, I. and McCluskey, P. (2012) Ocular Surface Disease and Quality of Life in Patients with Glaucoma. American Journal of Ophthalmology, 153, 1003-1004.

[30] Nelson, P., Aspinall, P., Papasouliotis, O., Worton, B. and O’Brien, C. (2003) Quality of Life in Glaucoma and Its Relationship with Visual Function. Journal of Glaucoma, 12, 139-150. http://dx.doi.org/10.1097/00061198-200304000-00009

[31] Iester, M. and Zingirian, M. (2002) Quality of Life in Patients with Early, Moderate and Advanced Glaucoma. Eye, 16, 44-49. http://dx.doi.org/10.1038/sj.eye.6700036 
Scientific Research Publishing (SCIRP) is one of the largest Open Access journal publishers. It is currently publishing more than 200 open access, online, peer-reviewed journals covering a wide range of academic disciplines. SCIRP serves the worldwide academic communities and contributes to the progress and application of science with its publication.

Other selected journals from SCIRP are listed as below. Submit your manuscript to us via either submit@scirp.org or Online Submission Portal.
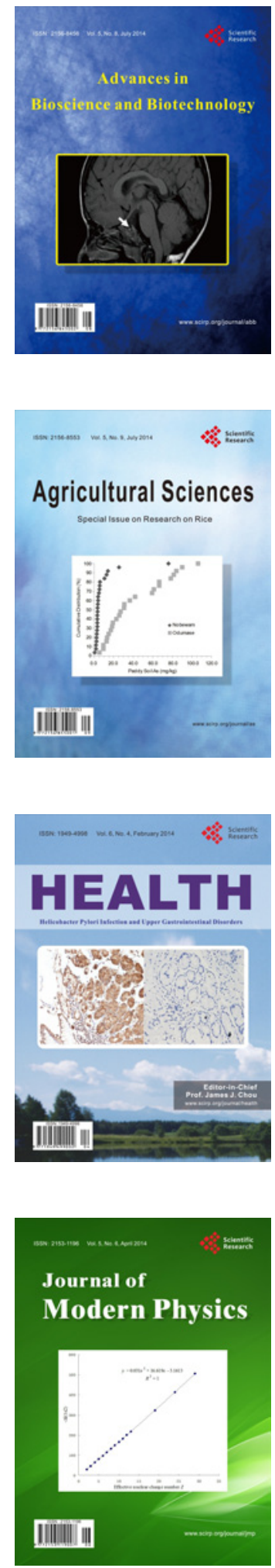
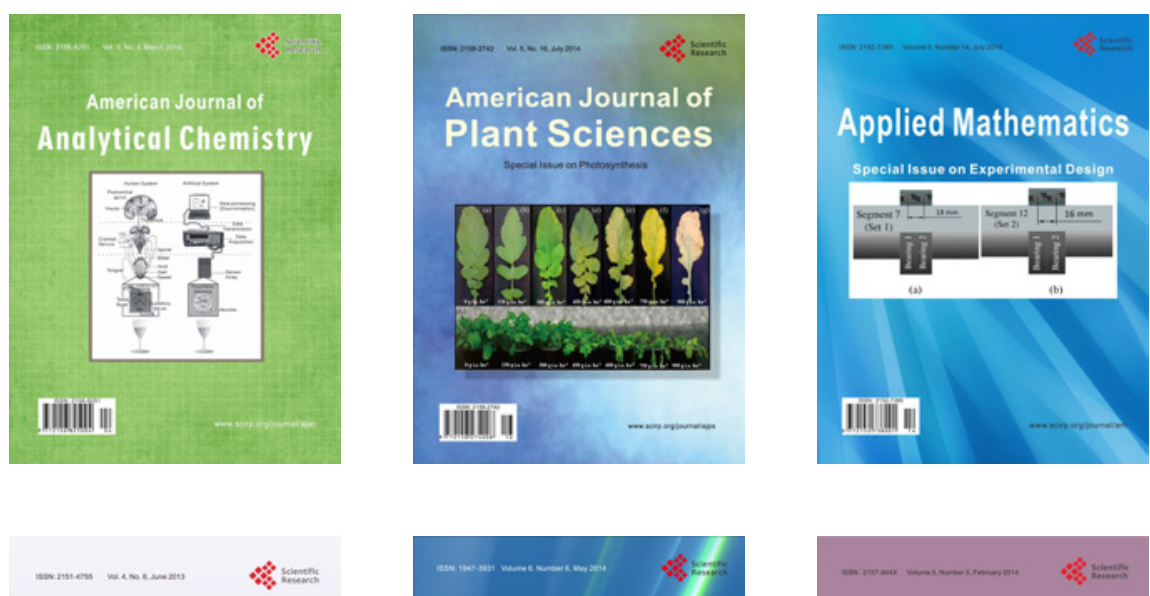

Creative Education
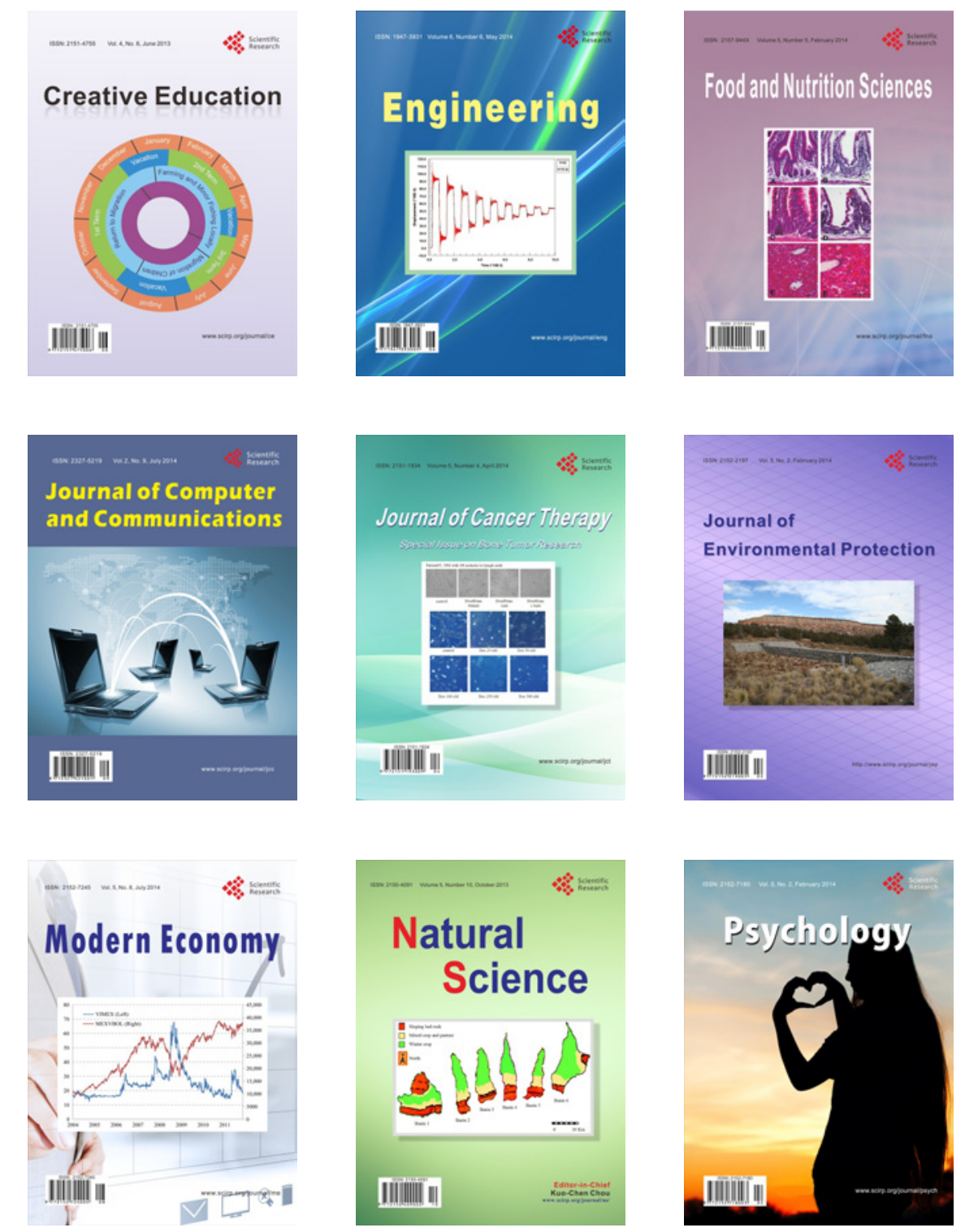